\title{
Growth Models for Lettuce Cultivars Growing in Spring
}

\author{
Fernanda Carini ${ }^{1}$, Alberto Cargnelutti Filho ${ }^{2}$, Cirineu Tolfo Bandeira ${ }^{1}$, Ismael Mario Marcio Neu ${ }^{1}$, \\ Rafael Vieira Pezzini ${ }^{1}$, Milena Pacheco ${ }^{3} \&$ Rosana Marzari Thomasi ${ }^{3}$ \\ ${ }^{1}$ Postgraduate Program in Agronomy, Federal University of Santa Maria, Santa Maria, Brazil \\ ${ }^{2}$ Department of Crop Science, Federal University of Santa Maria, Santa Maria, Rio Grande do Sul, Brazil \\ ${ }^{3}$ Student of Agronomy, Federal University of Santa Maria, Santa Maria, Brazil \\ Correspondence: Alberto Cargnelutti Filho, Department of Crop Science, Federal University of Santa Maria, \\ Avenida Roraima, ${ }^{\circ}$ 1000, Bairro Camobi, CEP 97105-900, Santa Maria, RS, Brazil. Tel: 55-55-3220-8899. \\ E-mail: alberto.cargnelutti.filho@gmail.com
}

Received: February 8, $2019 \quad$ Accepted: March 12, $2019 \quad$ Online Published: May 15, 2019
doi:10.5539/jas.v11n6p147
URL: https://doi.org/10.5539/jas.v11n6p147

\begin{abstract}
The objectives of this study were to adjust the Gompertz and logistic models to fit the fresh and dry matters of leaves and fresh and dry matters of shoots of four lettuce cultivars and indicate the model that best describes the growth in spring. Cultivars Ceres, Gloriosa, Grandes Lagos, and Rubinela were grown in protected environment and in soilless system, in the spring of 2016 and 2017. Seven days after transplantation, fresh and dry leaf matters and fresh and dry shoot matters were weighed every four days until beginning of flowering. The Gompertz and logistic models were adjusted as a function of accumulated thermal sum. The parameters of the Gompertz and logistic models and their confidence intervals were estimated, the assumptions of the models were verified, the goodness-of-fit measures and critical points were calculated, and the parametric and intrinsic nonlinearities quantified. The logistic and Gompertz growth models fitted well to fresh and dry leaf and shoot matters of cultivars Ceres, Gloriosa, Grandes Lagos, and Rubinela, under spring conditions. The logistic model is the most suitable to describe the growth of lettuce cultivars.
\end{abstract}

Keywords: Lactuca sativa L., non-linear models, growth curve, soilless cultivation, leaf green

\section{Introduction}

Lettuce (Lactuca sativa L.) is an annual leafy green vegetable originated from temperate climate and cultivated in several continents (Tadic et al., 2017). Its leaves are consumed without restrictions because of the high nutrient and fiber contents that provide health benefits (Martins, Butelli, Petroni, \& Tonelli, 2011; Kosma, Triantafyllidis, Papasavvas, Salahas, \& Patakas, 2013). It is a leafy green vegetable appreciated by the Brazilian population, justifying the production of 14 million plants annually (Santos et al., 2015).

Lettuce cultivars are classified into the group's iceberg, looseleaf (lollo and oakleaf), butterhead, romaine, and others, corresponding to $47.0 \%, 38.5 \%, 5.0 \%, 4.28 \%, 1.0 \%$, and $4.22 \%$, respectively, of the lettuce traded at CEAGESP-the General Warehousing Company of São Paulo (CEAGESP, 2017). Different genetic materials are on the market, with adaptations to growing seasons and morphological characteristics of leaves and head. Despite the protected environment, high summer and spring temperatures still compromise the quality and palatability of lettuce leaves. In Rio Grande do Sul, during the warmer months the average daily temperature varies from 18 to $26{ }^{\circ} \mathrm{C}$ (Kuinchtner \& Buriol, 2001), but the ideal temperature for the crop is between $15.5^{\circ} \mathrm{C}$ and $18.3^{\circ} \mathrm{C}$, with minimum of $7.2^{\circ} \mathrm{C}$ and maximum of $23.9^{\circ} \mathrm{C}$ (Maynard \& Hochmuth, 2007).

Statistical models can be used in studies involving animal or plant growth process. Nonlinear models provide estimates of parameters with biological interpretation (Fernandes, Pereira, Muniz, \& Savian, 2014). Thus, the models are an alternative for evaluating the growth curve of the crops, based on the accumulated thermal sum, and allow inferring on growth rate, stabilization, and reduction of production at the end of the cycle (Mischan \& Pinho, 2014).

Nonlinear models aim to condense information from a series of data, from a given period, into a set of biologically interpretable parameters (Terra, Muniz, \& Savian, 2010). The models were used in the plant production area to describe the accumulation of dry matter of garlic (Puiatti et al., 2013), the vegetative growth 
of coffee trees (Pereira, Fernandes, Scalco, \& Morais, 2016), and the modeling of yield traits of crotalaria (Bem et al., 2018). In addition, they were used to describe the production of zucchini and pepper (Lúcio, Nunes, \& Rego, 2015), strawberry (Diel et al., 2018), and salad-type tomato (Sari, Lúcio, Santana, \& Savian, 2019).

In studies with lettuce, the Gompertz, logistic, and expolinear models were adjusted for cultivar Grand Rapids to fit different concentrations of the nutrient solution in summer (Macedo, 2004). However, studies describing the growth of lettuce cultivars with nonlinear models in other seasons and grown in protected environment were not found.

We assume that the Gompertz and logistic models are suitable to describe the growth of four lettuce cultivars in spring and that it is possible to select the most appropriate model. The objectives of this study were to adjust the Gompertz and logistic models for the fresh and dry matters of leaves and shoots of four lettuce cultivars and indicate the model that best describes the growth in spring.

\section{Material and Methods}

We conducted two experiments with lettuce cultivars: one in the spring of 2016 (experiment 1) and the other in the spring of 2017 (experiment 2), in a protected environment in Santa Maria, Rio Grande do Sul State (29 $42^{\prime}$ S, $53^{\circ} 49^{\prime} \mathrm{W}$ and $95 \mathrm{~m}$ altitude). The climate of the region is humid subtropical Cfa, with hot summers and no defined dry season, according to Köppen classification (Alvares, Stape, Sentelhas, Gonçalves, \& Sparovek, 2013).

The cultivars evaluated were: Ceres (lollo-green crisp-consistent, loose leaves, and non-heading), Gloriosa and Grandes Lagos (iceberg-light green leaves, crisp, consistent, prominent ribs, compact head), and Rubinella (lollo, loose purple leaves, non-heading). The selection of these cultivars was based on the meteorological characteristics of the spring season and based on the seed companies' recommendations. Seedlings were produced in 200-cell expanded polystyrene trays filled with commercial Plantmax ${ }^{\circledR}$ substrate, in the floating system. Plants with four to five leaves were transplanted on 10/14/2016 (experiment 1) and 10/19/2017 (experiment 2).

Plants were grown in eight benches made of corrugated fiber cement sheets, $3.66 \mathrm{~m}$ long, $1.10 \mathrm{~m}$ wide, $6 \mathrm{~mm}$ thick, with six troughs of $5 \mathrm{~cm}$ in depth. The culture channels were waterproofed with clear plastic film of 100 $\mu \mathrm{m}$ and filled with washed gravel number two. The benches were raised $(0.85 \mathrm{~m})$ on fixed masonry blocks at the two end portions, with a $2 \%$ slope. This slope allowed the nutrient solution to return to the $500 \mathrm{~L}$ plastic storage tank. The solution was pumped by a low-power submersible motor pump (with a timer) to a PVC pipe ( $25 \mathrm{~mm}$ diameter). From this pipe derived four drip hoses with pots placed under the drippers at a distance of $30 \mathrm{~cm}$ between the plants in the row, to a plant density of $11.11 \mathrm{~m}^{-2}$. Each bench consisted of four rows, totaling 44 pots with $3 \mathrm{~L}$ volume (11 pots per row), filled with washed sieved coarse sand, with $0 \mathrm{dS} \mathrm{m}^{-1}$ electrical conductivity.

The macronutrient composition of the nutrient solution was as follows $\left(\mathrm{mmol} \mathrm{L}^{-1}\right): 10.36 \mathrm{NO}_{3}{ }^{-} ; 1.0 \mathrm{H}_{2} \mathrm{PO}_{4}^{-} ; 3.36$ $\mathrm{NH}_{4} ; 1.0 \mathrm{SO}_{4} ; 4.0 \mathrm{~K}^{+} ; 2.0 \mathrm{Ca}^{2+} ; 1.0 \mathrm{Mg}^{2+}$; and micronutrients $\left(\mathrm{mg} \mathrm{L}^{-1}\right): 1.0 \mathrm{Fe} ; 0.50 \mathrm{Mn} ; 0.22 \mathrm{Zn} ; 0.26 \mathrm{~B} ; 0.06$ $\mathrm{Cu}$ and $0.03 \mathrm{Mo}$, Mo for lettuce crop, with electrical conductivity (EC) maintained at $1.33 \mathrm{dS} \mathrm{m}^{-1}$ and $\mathrm{pH}$ between 5.5 and 6.5. EC and $\mathrm{pH}$ were monitored throughout the crop cycle and corrected when they showed a variation of $20 \%$, higher or lower, in relation to the standard.

The evaluations started with eight plants of each cultivar, at day seven after transplantation and were carried out every four days until the beginning of flowering. In experiment 1 , eight evaluations were carried out, totalizing 64 plants of each cultivar. In experiment 2 , ten evaluations were carried out, totalizing 80 plants of each cultivar. Including the four cultivars, in the two experiments, 576 plants were evaluated. These plants had fresh leaf matter (FLM, in g plant $\left.^{-1}\right)$, dry leaf matter (DLM, in g plant $\left.^{-1}\right)$, fresh shoot matter (FSM, in g plant ${ }^{-1}$ ) and dry shoot matter (DSM, in $\mathrm{g}_{\text {plant }}{ }^{-1}$ ), determined. To obtain the dry matters, the material was packed into paper bags and incubated in a forced circulation oven $\left(60 \pm 5^{\circ} \mathrm{C}\right)$ to constant matter.

Data on indoor air temperature were recorded every three hours by a digital data logger $\left(0.1{ }^{\circ} \mathrm{C}\right.$ resolution and $0.5^{\circ} \mathrm{C}$ accuracy) installed in a weather-proof shelter. We used these data to calculate the daily thermal sum by the method of Gilmore and Rogers (1958) and Arnold (1960), using Equations 1 and 2:

$$
\mathrm{STd}=(\operatorname{Tmax}+\mathrm{Tmin}) / 2-\mathrm{Tb}
$$

where, Tmax: maximum daily temperature as ${ }^{\circ} \mathrm{C}$; Tmin: daily minimum temperature as ${ }^{\circ} \mathrm{C}$; $\mathrm{Tb}$ : lettuce base temperature $=10^{\circ} \mathrm{C}$ (Brunini, 1976).

$$
\mathrm{aST}=\sum \mathrm{STd}
$$

where, aST: accumulated thermal sum; $\sum$ STd: sum of the daily thermal sum. 
The fitting of the Gompertz and logistic models to each trait (dependent variable) was performed with the repetitions of each evaluation as a function of the accumulated thermal sum (independent variable). The equation used for the Gompertz model (Windsor, 1932) was: $y_{i}=a \cdot \exp \left[-\exp \left(b-c x_{i}\right)\right]$, and for the logistic model (Nelder, 1961) was: $y_{i}=a /\left[1+\exp \left(-b-c x_{i}\right)\right]$, where yi is the $i-t h$ observation of the dependent variable with $i=1,2, \ldots n$; $\mathrm{xi}$ is the $\mathrm{i}$-th observation of the independent variable; $a$ is the asymptotic value; $b$ is a location parameter, important for maintaining the sigmoidal shape of the model; $c$ is associated with growth, indicating the precocity index.

The assumptions of normality, independence, and homogeneity of the model residuals were tested using the Shapiro-Wilk (Shapiro \& Wilk, 1965), Durbin-Watson (Durbin \& Watson, 1950), and Breusch-Pagan tests (Breusch \& Pagan, 1979) respectively. Data for the traits that did not fulfill these assumptions were Box-Cox transformed using the Action software.

The lower and upper limits of the $95 \%$ confidence interval were calculated and using the criterion of overlapping of the confidence intervals, the estimates of the parameters $(a, b$, and $c)$ for each trait were compared between the experiments in each cultivar, and between the cultivars in each experiment.

The goodness-of-fit of the model was tested using the adjusted coefficient of determination $\left(R^{2} a j\right)$ in which the best fit is the one that is closest to 1, and by the Akaike Information Criterion (AIC) and the residual standard deviation (RSD), in which the best fit for both is the one that is closest to zero. The intrinsic nonlinearity (IN) and the parameter-effects nonlinearity (PE) were quantified based on the geometric concept of curvature (Bates and Watts, 1988). To select the best model to describe the growth of the plants, we choose the one that provides the lowest intrinsic and parametric nonlinearity values. The inflection point (IP), the maximum acceleration point (MAP), and the maximum deceleration point (MDP) were calculated according to the equations described in Mischan and Pinho (2014). Inferences about plant growth were based on these critical points. The calculations were performed using the Microsoft Office Excel ${ }^{\circledR}$ applications and the software R (R Development Core Team, 2018).

\section{Results and Discussion}

The assumptions of normality, independence and homogeneity of errors for the Gompertz and logistic models, in the two experiments, fitted for fresh and dry leaf and shoot matters of the lettuce cultivars were met, with p-values greater than or equal to 0.05 obtained from the Shapiro-Wilk, Bartlett, and Durbin-Watson tests, respectively (Table 1). Bem et al. (2018) found similar results, in which the assumptions for the description of the yield traits of Crotalaria juncea were met.

Table 1. P-value of the Shapiro-Wilk (SW), Durbin-Watson (DW), and Breusch-Pagan (BP) tests applied on Gompertz and logistic residuals for characters as a function of cumulative thermal sum of four cultivars of lettuce in two experiments

\begin{tabular}{|c|c|c|c|c|c|c|c|}
\hline \multirow{2}{*}{ Character $^{(1)}$} & \multirow{2}{*}{ Cultivars } & \multicolumn{3}{|c|}{ Gompertz } & \multicolumn{3}{|c|}{ Logistic } \\
\hline & & SW & DW & $\mathrm{BP}$ & SW & DW & $\mathrm{BP}$ \\
\hline \multicolumn{8}{|c|}{ Experiment 1: Spring 2016} \\
\hline \multirow{4}{*}{ FLM } & Ceres & 0.72 & 0.06 & 0.27 & 0.61 & 0.07 & 0.31 \\
\hline & Gloriosa & 0.95 & 0.72 & 0.05 & 0.91 & 0.09 & 0.25 \\
\hline & Grandes Lagos & 0.98 & 0.80 & 0.21 & 0.88 & 0.22 & 0.45 \\
\hline & Rubinela & 0.76 & 0.08 & 0.10 & 0.47 & 0.10 & 0.33 \\
\hline \multirow{4}{*}{ DLM } & Ceres & 0.86 & 0.08 & 0.19 & 0.67 & 0.12 & 0.63 \\
\hline & Gloriosa & 0.11 & 0.05 & 0.07 & 0.25 & 0.09 & 0.05 \\
\hline & Grandes Lagos & 0.63 & 0.06 & 0.07 & 0.93 & 0.06 & 0.29 \\
\hline & Rubinela & 0.48 & 0.07 & 0.05 & 0.90 & 0.07 & 0.06 \\
\hline \multirow{4}{*}{ FSM } & Ceres & 0.77 & 0.08 & 0.15 & 0.48 & 0.09 & 0.22 \\
\hline & Gloriosa & 0.98 & 0.05 & 0.05 & 0.86 & 0.06 & 0.40 \\
\hline & Grandes Lagos & 0.98 & 0.34 & 0.18 & 0.80 & 0.32 & 0.31 \\
\hline & Rubinela & 0.82 & 0.06 & 0.14 & 0.53 & 0.05 & 0.43 \\
\hline \multirow{4}{*}{ DSM } & Ceres & 0.90 & 0.10 & 0.28 & 0.53 & 0.09 & 0.66 \\
\hline & Gloriosa & 0.14 & 0.05 & 0.06 & 0.19 & 0.06 & 0.08 \\
\hline & Grandes Lagos & 0.81 & 0.07 & 0.09 & 0.96 & 0.10 & 0.40 \\
\hline & Rubinela & 0.56 & 0.08 & 0.05 & 0.06 & 0.05 & 0.09 \\
\hline
\end{tabular}




\begin{tabular}{llllllll}
\hline Experiment 2: Spring 2017 & & & & & \\
& Ceres & 0.54 & 0.94 & 0.26 & 0.74 & 0.05 & 0.83 \\
FLM & Gloriosa & 0.14 & 0.62 & 0.09 & 0.21 & 0.26 & 0.05 \\
& Grandes Lagos & 0.39 & 0.94 & 0.44 & 0.89 & 0.64 & 0.44 \\
& Rubinela & 0.22 & 0.40 & 0.05 & 0.10 & 0.50 & 0.52 \\
\multirow{2}{*}{ DLM } & Ceres & 0.92 & 0.11 & 0.10 & 0.45 & 0.06 & 0.84 \\
& Gloriosa & 0.62 & 0.05 & 0.07 & 0.18 & 0.05 & 0.44 \\
& Grandes Lagos & 0.93 & 0.07 & 0.13 & 0.72 & 0.06 & 0.06 \\
\multirow{3}{*}{ FSM } & Rubinela & 0.63 & 0.65 & 0.11 & 0.93 & 0.47 & 0.58 \\
& Ceres & 0.77 & 0.76 & 0.33 & 0.75 & 0.09 & 0.80 \\
$\cdots$ & Gloriosa & 0.13 & 0.78 & 0.07 & 0.14 & 0.31 & 0.09 \\
DSM & Grandes Lagos & 0.34 & 0.94 & 0.45 & 0.87 & 0.58 & 0.42 \\
& Rubinela & 0.15 & 0.43 & 0.08 & 0.15 & 0.50 & 0.48 \\
& Ceres & 0.97 & 0.11 & 0.05 & 0.32 & 0.06 & 0.92 \\
& Gloriosa & 0.48 & 0.06 & 0.09 & 0.17 & 0.10 & 0.31 \\
\hline
\end{tabular}

Note. ${ }^{(1)}$ FLM = fresh leaf matter; DLM = dry leaf matter; FSM = fresh shoot matter; and DSM = dry shoot matter.

For all traits of the cultivars, the asymptotic values $(a)$, which represent the maximum matter increment, were higher in the Gompertz model than in the logistic model (Tables 2 and 3). The estimates of parameter $c$, which represents the growth rate, were higher in the logistic model (Tables 2 and 3).

Table 2. Estimation of the parameters $a, b$, and $c$, lower limit (LL) and upper limit (UL) of the confidence interval (C195\%) of the Gompertz model for the characters as a function of accumulated thermal sum $\left(\right.$ as $\left.{ }^{\circ} \mathrm{C}\right)$ of lettuce cultivars (Ceres, Gloriosa, Grandes Lagos e Rubinela) in two experiments

\begin{tabular}{|c|c|c|c|c|c|c|c|}
\hline \multirow{3}{*}{ Character (1) } & \multirow{3}{*}{ Parameter } & \multicolumn{3}{|c|}{ Experiment 1: Spring, 2016} & \multicolumn{3}{|c|}{ Experiment 2: Spring, 2017} \\
\hline & & \multirow{2}{*}{ Estimates } & \multicolumn{2}{|c|}{ IC95\% } & \multirow{2}{*}{ Estimates } & \multicolumn{2}{|c|}{ IC95\% } \\
\hline & & & $\overline{L L}$ & UL & & $\overline{L L}$ & UL \\
\hline \multicolumn{8}{|l|}{ Ceres } \\
\hline & $a(*)$ & 312.1481 & 278.2443 & 346.0520 & 750.2246 & 443.4583 & 1056.9908 \\
\hline \multirow[t]{3}{*}{ FLM } & $b(*)$ & 3.6242 & 2.8703 & 4.3781 & 2.2751 & 2.0317 & 2.5185 \\
\hline & $c(*)$ & 0.0108 & 0.0083 & 0.0134 & 0.0042 & 0.0030 & 0.0053 \\
\hline & $a(\mathrm{~ns})$ & 28.3716 & 21.2897 & 35.4536 & 30.0257 & 19.1948 & 40.8565 \\
\hline \multirow[t]{3}{*}{ DLM } & $b(\mathrm{~ns})$ & 2.4230 & 2.0355 & 2.8104 & 2.2653 & 1.9238 & 2.6069 \\
\hline & $c(\mathrm{~ns})$ & 0.0060 & 0.0044 & 0.0076 & 0.0048 & 0.0033 & 0.0063 \\
\hline & $a(*)$ & 427.8148 & 361.0197 & 494.6099 & 1003.7866 & 507.1240 & 1500.4492 \\
\hline \multirow[t]{3}{*}{ FSM } & $b(*)$ & 3.1176 & 2.5210 & 3.7141 & 2.2607 & 2.0421 & 2.4793 \\
\hline & $c(*)$ & 0.0085 & 0.0064 & 0.0106 & 0.0038 & 0.0027 & 0.0049 \\
\hline & $a(\mathrm{~ns})$ & 43.8345 & 25.6849 & 61.9841 & 39.2241 & 22.3457 & 56.1025 \\
\hline \multirow[t]{2}{*}{ DSM } & $b(\mathrm{~ns})$ & 2.2446 & 1.9253 & 2.5638 & 2.2307 & 1.9333 & 2.5281 \\
\hline & $c(\mathrm{~ns})$ & 0.0047 & 0.0032 & 0.0063 & 0.0043 & 0.0029 & 0.0057 \\
\hline \multicolumn{8}{|l|}{ Gloriosa } \\
\hline & $a(\mathrm{~ns})$ & 692.3494 & 475.8664 & 908.8323 & 633.3563 & 455.2993 & 811.4133 \\
\hline \multirow[t]{3}{*}{ FLM } & $b(\mathrm{~ns})$ & 2.4516 & 2.0094 & 2.8937 & 2.7182 & 2.2074 & 3.2290 \\
\hline & $c(\mathrm{~ns})$ & 0.0058 & 0.0040 & 0.0077 & 0.0061 & 0.0043 & 0.0079 \\
\hline & $a(\mathrm{~ns})$ & 18.9974 & 15.4884 & 22.5065 & 19.5761 & 15.7532 & 23.3990 \\
\hline \multirow[t]{3}{*}{ DLM } & $b(\mathrm{~ns})$ & 2.9768 & 2.0791 & 3.8746 & 2.5549 & 2.0452 & 3.0645 \\
\hline & $c(\mathrm{~ns})$ & 0.0091 & 0.0058 & 0.0125 & 0.0068 & 0.0049 & 0.0087 \\
\hline & $a(\mathrm{~ns})$ & 816.0510 & 532.2432 & 1099.8587 & 677.1060 & 483.7648 & 870.4472 \\
\hline \multirow[t]{3}{*}{ FSM } & $b(\mathrm{~ns})$ & 2.3874 & 1.9974 & 2.7774 & 2.7137 & 2.2156 & 3.2118 \\
\hline & $c(\mathrm{~ns})$ & 0.0054 & 0.0037 & 0.0071 & 0.0060 & 0.0043 & 0.0078 \\
\hline & $a(\mathrm{~ns})$ & 20.5879 & 16.6625 & 24.5132 & 21.3163 & 16.7958 & 25.8369 \\
\hline \multirow[t]{2}{*}{ DSM } & $b$ (ns) & 2.9297 & 2.0800 & 3.7793 & 2.5509 & 2.0286 & 3.0732 \\
\hline & $c(\mathrm{~ns})$ & 0.0088 & 0.0057 & 0.0120 & 0.0067 & 0.0047 & 0.0086 \\
\hline
\end{tabular}




\begin{tabular}{|c|c|c|c|c|c|c|c|}
\hline \multicolumn{8}{|c|}{ Grandes Lagos } \\
\hline & $a(*)$ & 534.6712 & 418.9440 & 650.3983 & 1062.3655 & 585.4987 & 1539.2323 \\
\hline \multirow[t]{3}{*}{ FLM } & $b$ (ns) & 2.7902 & 2.2829 & 3.2976 & 2.2928 & 2.0175 & 2.5682 \\
\hline & $c(\mathrm{~ns})$ & 0.0071 & 0.0052 & 0.0090 & 0.0042 & 0.0029 & 0.0055 \\
\hline & $a(\mathrm{~ns})$ & 25.6114 & 21.3975 & 29.8252 & 25.8669 & 15.5527 & 36.1811 \\
\hline \multirow[t]{3}{*}{ DLM } & $b$ (ns) & 3.0330 & 2.4268 & 3.6392 & 2.3410 & 1.6217 & 3.0603 \\
\hline & $c(\mathrm{~ns})$ & 0.0084 & 0.0062 & 0.0105 & 0.0059 & 0.0030 & 0.0088 \\
\hline & $a(\mathrm{~ns})$ & 726.7452 & 492.9028 & 960.5876 & 1269.4461 & 617.4770 & 1921.4152 \\
\hline \multirow[t]{3}{*}{ FSM } & $b(\mathrm{~ns})$ & 2.5914 & 2.1254 & 3.0575 & 2.2855 & 2.0157 & 2.5554 \\
\hline & $c(*)$ & 0.0060 & 0.0041 & 0.0078 & 0.0040 & 0.0027 & 0.0053 \\
\hline & $a(\mathrm{~ns})$ & 30.8455 & 24.5910 & 37.1000 & 29.2898 & 16.9617 & 41.6180 \\
\hline \multirow[t]{2}{*}{ DSM } & $b$ (ns) & 2.8457 & 2.2982 & 3.3932 & 2.3362 & 1.6441 & 3.0283 \\
\hline & $c(\mathrm{~ns})$ & 0.0074 & 0.0054 & 0.0095 & 0.0058 & 0.0029 & 0.0086 \\
\hline \multicolumn{8}{|c|}{ Rubinela } \\
\hline & $a(\mathrm{~ns})$ & 408.3864 & 39.5865 & 777.1864 & 551.1602 & 321.4904 & 780.8299 \\
\hline \multirow[t]{3}{*}{ FLM } & $b(\mathrm{~ns})$ & 2.4535 & 1.9245 & 2.9824 & 2.3328 & 2.0411 & 2.6245 \\
\hline & $c(\mathrm{~ns})$ & 0.0045 & 0.0020 & 0.0070 & 0.0044 & 0.0031 & 0.0057 \\
\hline & $a(\mathrm{~ns})$ & 31.9655 & -12.4523 & 76.3832 & 15.2111 & 10.8093 & 19.6130 \\
\hline \multirow[t]{3}{*}{ DLM } & $b$ (ns) & 2.2157 & 1.8910 & 2.5404 & 2.4490 & 1.9645 & 2.9335 \\
\hline & $c(*)$ & 0.0034 & 0.0011 & 0.0057 & 0.0058 & 0.0039 & 0.0077 \\
\hline & $a(\mathrm{~ns})$ & 591.4820 & -89.5338 & 1272.4979 & 638.9751 & 355.8407 & 922.1094 \\
\hline \multirow[t]{3}{*}{ FSM } & $b$ (ns) & 2.4086 & 1.9587 & 2.8585 & 2.3275 & 2.0514 & 2.6035 \\
\hline & $c(\mathrm{~ns})$ & 0.0040 & 0.0016 & 0.0063 & 0.0042 & 0.0030 & 0.0055 \\
\hline & $a(\mathrm{~ns})$ & 44.2640 & -31.5674 & 120.0955 & 17.2401 & 11.9484 & 22.5319 \\
\hline \multirow[t]{2}{*}{ DSM } & $b$ (ns) & 2.2109 & 1.9439 & 2.4780 & 2.4282 & 1.9708 & 2.8856 \\
\hline & $c(*)$ & 0.0031 & 0.0008 & 0.0054 & 0.0056 & 0.0038 & 0.0074 \\
\hline
\end{tabular}

Note $^{(1)} \mathrm{FLM}=$ fresh leaf matter, as $\mathrm{g} \mathrm{plant}^{-1} ; \mathrm{DLM}=$ dry leaf matter, as $\mathrm{g}$ plant ${ }^{-1} ; \mathrm{FSM}=$ fresh shoot matter, as $\mathrm{g}$ plant $^{-1}$; and DSM $=$ dry shoot matter, as g plant ${ }^{-1} \cdot{ }^{(2)}$ Comparison of the parameters estimates $(a, b$ and $c)$ between the experiments: * Significant effect at $5 \%$ probability of error. ns Non-significant.

The estimates of the parameters $(a, b$ and $c)$ of each trait for the Gompertz and logistic models were compared between the experiments (Tables 2 and 3 ) and between the cultivars (Tables 4 ) using the criterion of overlapping confidence intervals.

By way of illustration of the comparison using the criterion of overlapping $95 \%$ confidence intervals (CI95\%), the FLM of cv. Ceres, in the comparison of the estimate of parameter $a$ of the logistic model between experiments 1 and 2 (Table 3), we found that the estimate of parameter $a$ (287.2396 in experiment 1 lies outside the confidence interval of the estimate of parameter $a$ in experiment 2 (344.4126 to 458.7919). As well, the estimate of parameter $a$ (401.6022 in experiment 2 lies outside the confidence interval of the estimate of parameter $a$ of experiment 1 (267.9975 to 306.4818). Therefore, the estimates of the parameter a are different between the experiments. Thus, if the two parameter estimates lie outside the CI of the other, we can conclude that the effect is significant. However, when at least one of the estimates is within the $\mathrm{CI}$ of the other, the effect is non-significant.

Tabela 3. Estimation of the parameters $a, b$, and $c$, lower limit (LL) and upper limit (UL) of the confidence interval (CI95\%) of the logistic model for the characters as a function of accumulated thermal sum (as $\left.{ }^{\circ} \mathrm{C}\right)$ of lettuce cultivars (Ceres, Gloriosa, Grandes Lagos e Rubinela) in two experiments, in spring

\begin{tabular}{|c|c|c|c|c|c|c|c|}
\hline \multirow{3}{*}{ Character $^{(1)}$} & \multirow{3}{*}{ Parameter } & \multicolumn{3}{|c|}{ Experiment 1: Spring, 2016} & \multicolumn{3}{|c|}{ Experiment 2: Spring, 2017} \\
\hline & & \multirow{2}{*}{ Estimates } & \multicolumn{2}{|c|}{ IC95\% } & \multirow{2}{*}{ Estimates } & \multicolumn{2}{|c|}{ IC95\% } \\
\hline & & & LL & UL & & LL & UL \\
\hline \multicolumn{8}{|l|}{ Ceres } \\
\hline & $a(*)$ & 287.2396 & 267.9975 & 306.4818 & 401.6022 & 344.4126 & 458.7919 \\
\hline \multirow[t]{2}{*}{ FLM } & $b(*)$ & -6.6774 & -7.7433 & -5.6114 & -5.5844 & -6.0763 & -5.0924 \\
\hline & $c(*)$ & 0.0184 & 0.0152 & 0.0217 & 0.0117 & 0.0101 & 0.0133 \\
\hline
\end{tabular}




\begin{tabular}{|c|c|c|c|c|c|c|c|}
\hline & $a(\mathrm{~ns})$ & 21.1540 & 18.5834 & 23.7246 & 19.6631 & 16.8088 & 22.5175 \\
\hline \multirow[t]{3}{*}{ DLM } & $b(\mathrm{~ns})$ & -5.2971 & -5.9566 & -4.6375 & -5.2963 & -5.9246 & -4.6680 \\
\hline & $c(\mathrm{~ns})$ & 0.0130 & 0.0108 & 0.0153 & 0.0118 & 0.0098 & 0.0139 \\
\hline & $a(*)$ & 365.1177 & 334.9597 & 395.2757 & 472.7434 & 396.1543 & 549.3324 \\
\hline \multirow[t]{3}{*}{ FSM } & $b(\mathrm{~ns})$ & -6.2999 & -7.1941 & -5.4057 & -5.6615 & -6.1318 & -5.1911 \\
\hline & $c(*)$ & 0.0163 & 0.0136 & 0.0190 & 0.0115 & 0.0099 & 0.0131 \\
\hline & $a(\mathrm{~ns})$ & 27.6155 & 22.5652 & 32.6657 & 23.0673 & 19.3677 & 26.7669 \\
\hline \multirow[t]{2}{*}{ DSM } & $b(\mathrm{~ns})$ & -5.1854 & -5.7722 & -4.5986 & -5.3582 & -5.9374 & -4.7789 \\
\hline & $c(\mathrm{~ns})$ & 0.0117 & 0.0096 & 0.0139 & 0.0115 & 0.0096 & 0.0134 \\
\hline \multicolumn{8}{|c|}{ Gloriosa } \\
\hline & $a(\mathrm{~ns})$ & 496.2632 & 426.3758 & 566.1507 & 453.9529 & 403.4649 & 504.4415 \\
\hline \multirow[t]{3}{*}{ FLM } & $b(\mathrm{~ns})$ & -5.4758 & -6.2238 & -4.7278 & -6.2451 & -7.0797 & -5.4105 \\
\hline & $c(\mathrm{~ns})$ & 0.0132 & 0.0107 & 0.0157 & 0.0142 & 0.0118 & 0.0166 \\
\hline & $a(\mathrm{~ns})$ & 16.8884 & 15.1143 & 18.6626 & 16.1301 & 14.5857 & 17.6745 \\
\hline \multirow[t]{3}{*}{ DLM } & $b$ (ns) & -5.8116 & -7.1468 & -4.4764 & -5.4480 & -6.2682 & -4.6278 \\
\hline & $c(\mathrm{~ns})$ & 0.0165 & 0.0122 & 0.0209 & 0.0138 & 0.0112 & 0.0163 \\
\hline & $a(\mathrm{~ns})$ & 551.5944 & 468.3603 & 634.8285 & 479.2687 & 425.8834 & 532.6539 \\
\hline \multirow[t]{3}{*}{ FSM } & $b(*)$ & -5.4480 & -6.1282 & -4.7678 & -6.2698 & -7.0848 & -5.4547 \\
\hline & $c(\mathrm{~ns})$ & 0.0128 & 0.0105 & 0.0151 & 0.0142 & 0.0118 & 0.0165 \\
\hline & $a(\mathrm{~ns})$ & 18.1122 & 16.1877 & 20.0367 & 17.3582 & 15.5845 & 19.1319 \\
\hline \multirow[t]{2}{*}{ DSM } & $b(\mathrm{~ns})$ & -5.7801 & -7.0547 & -4.5055 & -5.4797 & -6.3212 & -4.6382 \\
\hline & $c(\mathrm{~ns})$ & 0.0162 & 0.0121 & 0.0203 & 0.0137 & 0.0111 & 0.0163 \\
\hline \multicolumn{8}{|c|}{ Grandes Lagos } \\
\hline & $a(*)$ & 417.3851 & 375.2177 & 459.5525 & 569.7647 & 480.7629 & 658.7665 \\
\hline \multirow[t]{3}{*}{ FLM } & $b(\mathrm{~ns})$ & -6.0415 & -6.8486 & -5.2345 & -5.6229 & -6.1758 & -5.0699 \\
\hline & $c(*)$ & 0.0150 & 0.0125 & 0.0175 & 0.0118 & 0.0100 & 0.0136 \\
\hline & $a(\mathrm{~ns})$ & 21.5397 & 19.7628 & 23.3166 & 20.1482 & 16.2920 & 24.0044 \\
\hline \multirow[t]{3}{*}{ DLM } & $b(\mathrm{~ns})$ & -6.2871 & -7.2299 & -5.3443 & -5.0677 & -6.2884 & -3.8471 \\
\hline & $c(\mathrm{~ns})$ & 0.0165 & 0.0136 & 0.0194 & 0.0125 & 0.0085 & 0.0165 \\
\hline & $a(*)$ & 505.5648 & 436.9364 & 574.1933 & 638.3743 & 527.4652 & 749.2834 \\
\hline \multirow[t]{3}{*}{ FSM } & $b(\mathrm{~ns})$ & -5.9252 & -6.7097 & -5.1406 & -5.6638 & -6.2209 & -5.1066 \\
\hline & $c(\mathrm{~ns})$ & 0.0140 & 0.0114 & 0.0165 & 0.0117 & 0.0098 & 0.0135 \\
\hline & $a(\mathrm{~ns})$ & 24.5988 & 22.2425 & 26.9551 & 22.3294 & 17.9162 & 26.7427 \\
\hline \multirow[t]{2}{*}{ DSM } & $b(\mathrm{~ns})$ & -6.1097 & -6.9897 & -5.2297 & -5.1075 & -6.2876 & -3.9274 \\
\hline & $c(\mathrm{~ns})$ & 0.0155 & 0.0128 & 0.0182 & 0.0124 & 0.0085 & 0.0162 \\
\hline \multicolumn{8}{|c|}{ Rubinela } \\
\hline & $a(*)$ & 195.2048 & 140.7449 & 249.6647 & 307.3870 & 262.5747 & 352.1993 \\
\hline \multirow[t]{3}{*}{ FLM } & $b(\mathrm{~ns})$ & -6.2692 & -7.3033 & -5.2351 & -5.6991 & -6.2629 & -5.1352 \\
\hline & $c(\mathrm{~ns})$ & 0.0134 & 0.0100 & 0.0169 & 0.0121 & 0.0102 & 0.0139 \\
\hline & $a(\mathrm{~ns})$ & 11.8430 & 6.7680 & 16.9179 & 11.2851 & 9.8991 & 12.6710 \\
\hline \multirow[t]{3}{*}{ DLM } & $b(\mathrm{~ns})$ & -5.6258 & -6.3884 & -4.8632 & -5.5331 & -6.3562 & -4.7099 \\
\hline & $c(\mathrm{~ns})$ & 0.0114 & 0.0082 & 0.0145 & 0.0131 & 0.0106 & 0.0157 \\
\hline & $a(*)$ & 231.1328 & 157.0969 & 305.1687 & 339.1037 & 287.9442 & 390.2633 \\
\hline \multirow[t]{3}{*}{ FSM } & $b(\mathrm{~ns})$ & -6.3331 & -7.2960 & -5.3702 & -5.7433 & -6.2883 & -5.1984 \\
\hline & $c(\mathrm{~ns})$ & 0.0132 & 0.0099 & 0.0165 & 0.0120 & 0.0102 & 0.0137 \\
\hline & $a(\mathrm{~ns})$ & 13.6390 & 6.8765 & 20.4014 & 12.4051 & 10.8351 & 13.9752 \\
\hline \multirow[t]{2}{*}{ DSM } & $b(\mathrm{~ns})$ & -5.6868 & -6.4001 & -4.9734 & -5.5512 & -6.3377 & -4.7647 \\
\hline & $c(\mathrm{~ns})$ & 0.0111 & 0.0081 & 0.0142 & 0.0129 & 0.0105 & 0.0154 \\
\hline
\end{tabular}

$\overline{\text { Note. }}{ }^{(1)} \mathrm{FLM}=$ fresh leaf matter, as $\mathrm{g} \mathrm{plant}^{-1} ; \mathrm{DLM}=$ dry leaf matter, as $\mathrm{g}$ plant $^{-1} ; \mathrm{FSM}=$ fresh shoot matter, as $\mathrm{g}$ plant $^{-1}$; and DSM $=$ dry shoot matter, as g plant ${ }^{-1} \cdot{ }^{(2)}$ Comparison of the parameters estimates $(a, b$ and $c)$ between the experiments: * Significant effect at $5 \%$ probability of error. ns: Non-significant. 
The Gompertz model showed no difference for the parameters $a, b$ and $c$ for DLM and DSM of cv. Ceres between the experiments (Table 2). On the other hand, the parameters differed for FLM and FSM, with higher asymptotic values in experiment 2, indicating a greater matter production than in experiment 1 . The estimates of all traits for cultivars Gloriosa and Rubinela were not different, except for the parameter $c$ of DLM and DSM of cv. Rubinela. Finally, cv. Grandes Lagos showed no difference for the parameters for the traits DLM and DSM, but FLM and FSM differed for the parameters $a$ and $c$, respectively. These results indicate that, for most cultivars, there was no difference in the estimates of the Gompertz model between the experiments.

In the logistic model, the parameters $a, b$, and $c$ of the traits DLM and DSM of all cultivars were not different between the experiments (Table 3), and the same occurred with FLM of cv. Gloriosa, whereas cv. Ceres showed no difference for $b$ of FSM. Higher asymptotic values were also found in experiment 2, which indicates higher matter production in relation to experiment 1. Cultivar Grandes Lagos showed no difference for parameters $a$ and $c$ of FLM and for FSM. Cultivar Rubinela differed between the experiments only for the asymptotic values of FLM and FSM. Thus, we can infer that there was no difference for most parameter estimates between the experiments for the same cultivar.

The comparison of cultivars in each experiment showed that in the Gompertz model, in experiment 1, there was no difference between the cultivars Gloriosa and Grandes Lagos and Gloriosa and Rubinela for all parameters of the traits FLM and FSM, as well as Grandes Lagos and Rubinela for FSM and Ceres and Rubinela for DSM (Table 4). These results indicate that the Gompertz model does not differ between these cultivars. In contrast, the Gompertz model differed for all traits of the cultivars Ceres and Gloriosa, since at least one of the three parameters $(a, b$, and $c)$ was significant. Similar behavior was observed between the cultivars Ceres and Grandes Lagos. In experiment 2, the cultivars Ceres and Grades Lagos showed no difference for any of the traits, and Gloriosa and Rubinela showed no difference for FLM, DLM, and DSM. Gloriosa and Grandes Lagos were also similar regarding DLM, and DSM, Ceres and Rubinela for FLM and DLM, and Gloriosa and Rubinela for FSM and DSM. These results show that in experiment 2, the difference between the estimates of the parameters of the Gompertz model reduced.

Table 4. Comparison of estimates of parameters $(a, b$ and $c$ ) in the Gompertz and logistic models for characters as a function of cumulative thermal sum based on the confidence interval (CI 95\%), between lettuce cultivars Ceres, Gloriosa, Grandes Lagos and Rubinela, in two experiments, in spring

\begin{tabular}{|c|c|c|c|c|c|c|c|c|c|}
\hline \multirow{2}{*}{ Cultivar } & \multirow{2}{*}{ Cultivar } & \multicolumn{4}{|c|}{ Experiment 1: Spring, 2016} & \multicolumn{4}{|c|}{ Experiment 2: Spring, 2017} \\
\hline & & FLM & DLM & FSM & DSM & FLM & DLM & FSM & DSM \\
\hline \multicolumn{10}{|l|}{ Gompertz } \\
\hline \multicolumn{10}{|l|}{$a$} \\
\hline Ceres & Gloriosa & $*$ & $*$ & $*$ & $*$ & ns & ns & ns & $*$ \\
\hline Ceres & Grandes Lagos & $*$ & ns & $*$ & ns & ns & ns & ns & ns \\
\hline Ceres & Rubinela & ns & ns & ns & ns & ns & $*$ & ns & $*$ \\
\hline Gloriosa & Grandes Lagos & ns & $*$ & ns & $*$ & ns & ns & ns & ns \\
\hline Gloriosa & Rubinela & ns & ns & ns & ns & ns & ns & ns & ns \\
\hline Grandes Lagos & Rubinela & ns & ns & ns & ns & $*$ & $*$ & ns & $\mathrm{ns}$ \\
\hline \multicolumn{10}{|l|}{$b$} \\
\hline Ceres & Gloriosa & $*$ & ns & $*$ & ns & ns & ns & ns & ns \\
\hline Ceres & Grandes Lagos & $*$ & $*$ & ns & $*$ & ns & ns & ns & ns \\
\hline Ceres & Rubinela & $*$ & ns & $*$ & ns & ns & ns & ns & ns \\
\hline Gloriosa & Grandes Lagos & ns & ns & ns & ns & ns & ns & ns & ns \\
\hline Gloriosa & Rubinela & ns & ns & ns & ns & ns & ns & ns & ns \\
\hline Grandes Lagos & Rubinela & ns & $*$ & ns & $*$ & ns & ns & ns & ns \\
\hline \multicolumn{10}{|l|}{$c$} \\
\hline Ceres & Gloriosa & $*$ & ns & $*$ & $*$ & $*$ & $*$ & $*$ & $*$ \\
\hline Ceres & Grandes Lagos & $*$ & $*$ & $*$ & $*$ & ns & ns & ns & ns \\
\hline Ceres & Rubinela & $*$ & $*$ & $*$ & $\mathrm{~ns}$ & ns & ns & ns & ns \\
\hline Gloriosa & Grandes Lagos & ns & ns & ns & $\mathrm{ns}$ & $*$ & ns & $*$ & ns \\
\hline Gloriosa & Rubinela & ns & $*$ & ns & $*$ & ns & ns & $*$ & ns \\
\hline Grandes Lagos & Rubinela & $*$ & $*$ & ns & $*$ & $\mathrm{~ns}$ & ns & $\mathrm{ns}$ & $\mathrm{ns}$ \\
\hline
\end{tabular}




\begin{tabular}{|c|c|c|c|c|c|c|c|c|c|}
\hline \multicolumn{10}{|l|}{ Logístico } \\
\hline \multicolumn{10}{|l|}{$a$} \\
\hline Ceres & Gloriosa & $*$ & $*$ & $*$ & $*$ & ns & $*$ & ns & $*$ \\
\hline Ceres & Grandes Lagos & $*$ & ns & $*$ & ns & $*$ & ns & $*$ & ns \\
\hline Ceres & Rubinela & $*$ & $*$ & $*$ & $*$ & $*$ & $*$ & $*$ & $*$ \\
\hline Gloriosa & Grandes Lagos & $*$ & $*$ & ns & $*$ & $*$ & $*$ & $*$ & $*$ \\
\hline Gloriosa & Rubinela & $*$ & $\mathrm{~ns}$ & $*$ & ns & $*$ & $*$ & $*$ & $*$ \\
\hline Grandes Lagos & Rubinela & $*$ & $*$ & $*$ & $*$ & $*$ & $*$ & $*$ & $*$ \\
\hline \multicolumn{10}{|l|}{$b$} \\
\hline Ceres & Gloriosa & $*$ & $\mathrm{~ns}$ & $\mathrm{~ns}$ & ns & ns & ns & $*$ & ns \\
\hline Ceres & Grandes Lagos & ns & $*$ & ns & $*$ & ns & ns & ns & ns \\
\hline Ceres & Rubinela & ns & ns & ns & ns & ns & ns & ns & ns \\
\hline Gloriosa & Grandes Lagos & $\mathrm{ns}$ & $\mathrm{ns}$ & $\mathrm{ns}$ & $\mathrm{ns}$ & ns & $\mathrm{ns}$ & ns & ns \\
\hline Gloriosa & Rubinela & $\mathrm{ns}$ & ns & ns & ns & ns & ns & ns & ns \\
\hline Grandes Lagos & Rubinela & ns & $\mathrm{ns}$ & ns & ns & ns & ns & ns & ns \\
\hline \multicolumn{10}{|l|}{$c$} \\
\hline Ceres & Gloriosa & $*$ & $\mathrm{~ns}$ & $*$ & ns & $*$ & $\mathrm{~ns}$ & $*$ & $*$ \\
\hline Ceres & Grandes Lagos & $*$ & $*$ & ns & $*$ & ns & ns & ns & ns \\
\hline Ceres & Rubinela & $*$ & $\mathrm{~ns}$ & ns & ns & ns & ns & ns & ns \\
\hline Gloriosa & Grandes Lagos & $\mathrm{ns}$ & ns & ns & ns & ns & ns & $*$ & ns \\
\hline Gloriosa & Rubinela & ns & $*$ & ns & $*$ & ns & ns & ns & ns \\
\hline Grandes Lagos & Rubinela & ns & $*$ & ns & $*$ & ns & ns & ns & ns \\
\hline
\end{tabular}

Note. $\mathrm{FLM}=$ fresh leaf matter, as $\mathrm{g}$ plant $^{-1} ; \mathrm{DLM}=$ dry leaf matter, as $\mathrm{g} \mathrm{plant}^{-1} ; \mathrm{FSM}=$ fresh shoot matter, as $\mathrm{g}$ plant $^{-1}$; and DSM $=$ dry shoot matter, as g plant ${ }^{-1} \cdot{ }^{(2)}$ Comparison of the parameters estimates $(a, b$ and c) between the experiments: $*=$ Significant effect at $5 \%$ probability of error. $n s=$ Non-significant.

The estimates of the logistic model parameters for FSM of Gloriosa and Grandes Lagos in experiment 1 and for DLM and DSM of Ceres and Grandes Lagos in experiment 2 were not different (Table 4). In the other comparisons, difference was found in at least one of the three parameters of the logistic model. The logistic model requires specific models for each trait and cultivar, because the differences were predominant. Different models were also needed to estimate the production of salad-type tomato in two years of cultivation (Sari et al., 2019).

Goodness-of-fit measures are used to define the most appropriate model. The logistic and Gompertz models presented satisfactory values of goodness of fit (high $\mathrm{R}^{2}$, low AIC, and intermediate RSD) and close to each other (Tables 5 and 6). These measures were also used by Puiatti et al. (2013) for the selection of nonlinear models to describe dry matter accumulation in garlic.

The Gompertz and logistic models satisfactorily described the growth curve of lettuce cultivars, with $\mathrm{R}^{2}$ aj values greater than or equal to 0.850 , for both models. Macedo (2003) adjusted growth models for different nutrient solutions to fit dry leaf matter of cultivar Grace Lake, in summer, in Viçosa (Minas Gerais-Brazil), and found coefficients of determination greater than or equal to 0.98 for the Gompertz, logistic, and expolinear models. 
Table 5. Coefficient of determination $\left(\mathrm{R}^{2}\right)$, Akaike information criterion (AIC), residual standard deviation (RSD), intrinsic nonlinearity (IN), nonlinearity of the parameter effect (PE), inflection point (IP), maximum acceleration point (MAP), and maximum deceleration point (MDP) of the Gompertz model for characters ${ }^{(1)}$ as a function of the accumulated thermal sum (in ${ }^{\circ} \mathrm{C}$ ) of lettuce cultivars (Ceres, Gloriosa, Grandes Lagos e Rubinela) in two experiments

\begin{tabular}{|c|c|c|c|c|c|c|c|c|c|}
\hline \multirow{2}{*}{ Statistic } & & \multicolumn{4}{|c|}{ Experiment 1: Spring, 2016} & \multicolumn{4}{|c|}{ Experiment 2: Spring, 2017} \\
\hline & & FLM & DLM & FSM & DSM & FLM & DLM & FSM & DSM \\
\hline \multicolumn{10}{|l|}{ Ceres } \\
\hline$R^{2} a j$ & & 0.955 & 0.969 & 0.963 & 0.968 & 0.975 & 0.956 & 0.977 & 0.961 \\
\hline $\mathrm{AIC}$ & & 6.367 & 0.404 & 6.497 & 0.671 & 5.457 & 0.100 & 5.553 & 0.162 \\
\hline RSD & & 23.087 & 1.168 & 24.608 & 1.335 & 16.817 & 1.208 & 18.038 & 1.252 \\
\hline $\mathrm{PE}$ & & 1.100 & 3.671 & 1.805 & 7.877 & 8.606 & 6.022 & 11.962 & 8.205 \\
\hline IN & & 0.144 & 0.141 & 0.144 & 0.144 & 0.113 & 0.142 & 0.112 & 0.133 \\
\hline \multirow[t]{2}{*}{ IP } & $\mathrm{x}$ & 334.312 & 404.207 & 365.093 & 473.159 & 546.418 & 472.769 & 592.465 & 514.098 \\
\hline & $\mathrm{y}$ & 114.833 & 10.437 & 157.384 & 16.126 & 275.992 & 11.046 & 369.272 & 14.430 \\
\hline \multirow[t]{2}{*}{ MAP } & $\mathrm{x}$ & 245.533 & 243.653 & 252.385 & 270.278 & 315.268 & 271.913 & 340.240 & 292.290 \\
\hline & $\mathrm{y}$ & 22.770 & 2.070 & 31.208 & 3.198 & 54.726 & 2.190 & 73.222 & 2.861 \\
\hline \multirow[t]{2}{*}{ MDP } & $\mathrm{x}$ & 423.090 & 564.762 & 477.800 & 676.040 & 777.568 & 673.625 & 844.690 & 735.906 \\
\hline & $\mathrm{y}$ & 213.047 & 19.364 & 291.991 & 29.918 & 512.042 & 20.493 & 685.103 & 26.771 \\
\hline \multicolumn{10}{|l|}{ Gloriosa } \\
\hline$R^{2} a j$ & & 0.961 & 0.908 & 0.966 & 0.914 & 0.956 & 0.940 & 0.958 & 0.937 \\
\hline AIC & & 6.904 & 1.431 & 6.892 & 1.475 & 6.302 & 0.145 & 6.326 & 0.202 \\
\hline RSD & & 30.129 & 1.953 & 29.957 & 1.996 & 30.566 & 1.381 & 31.180 & 1.502 \\
\hline PE & & 4.818 & 2.021 & 5.846 & 2.118 & 4.095 & 2.327 & 4.237 & 2.579 \\
\hline IN & & 0.160 & 0.244 & 0.151 & 0.234 & 0.165 & 0.170 & 0.162 & 0.175 \\
\hline \multirow[t]{2}{*}{ IP } & $\mathrm{x}$ & 419.999 & 325.987 & 442.550 & 331.513 & 444.443 & 375.311 & 449.647 & 382.306 \\
\hline & $\mathrm{y}$ & 254.701 & 6.989 & 300.208 & 7.574 & 232.999 & 7.202 & 249.093 & 7.842 \\
\hline \multirow{2}{*}{ MAP } & $\mathrm{x}$ & 255.117 & 220.593 & 264.148 & 222.607 & 287.082 & 233.932 & 290.179 & 238.069 \\
\hline & $\mathrm{y}$ & 50.504 & 1.386 & 59.528 & 1.502 & 46.201 & 1.428 & 49.392 & 1.555 \\
\hline \multirow[t]{2}{*}{ MDP } & $\mathrm{x}$ & 584.881 & 431.380 & 620.953 & 440.419 & 601.804 & 516.689 & 609.115 & 526.543 \\
\hline & $\mathrm{y}$ & 472.541 & 12.966 & 556.970 & 14.052 & 432.277 & 13.361 & 462.137 & 14.549 \\
\hline \multicolumn{10}{|c|}{ Grandes Lagos } \\
\hline$R^{2} a j$ & & 0.966 & 0.960 & 0.965 & 0.962 & 0.970 & 0.853 & 0.969 & 0.862 \\
\hline AIC & & 6.561 & 0.967 & 6.823 & 1.076 & 6.395 & 1.695 & 6.519 & 1.780 \\
\hline RSD & & 25.398 & 1.549 & 28.936 & 1.635 & 26.457 & 2.703 & 29.064 & 2.836 \\
\hline PE & & 2.879 & 1.914 & 5.085 & 2.574 & 9.405 & 5.167 & 11.581 & 5.652 \\
\hline IN & & 0.144 & 0.154 & 0.152 & 0.151 & 0.127 & 0.263 & 0.130 & 0.257 \\
\hline \multirow[t]{2}{*}{ IP } & $\mathrm{x}$ & 393.916 & 362.054 & 434.393 & 381.972 & 545.019 & 394.544 & 568.836 & 406.217 \\
\hline & $\mathrm{y}$ & 196.695 & 9.422 & 267.354 & 11.347 & 390.822 & 9.516 & 467.003 & 10.775 \\
\hline \multirow[t]{2}{*}{ MAP } & $\mathrm{x}$ & 258.044 & 247.168 & 273.066 & 252.786 & 316.246 & 232.339 & 329.303 & 238.872 \\
\hline & $\mathrm{y}$ & 39.002 & 1.868 & 53.013 & 2.250 & 77.495 & 1.887 & 92.601 & 2.137 \\
\hline \multirow[t]{2}{*}{ MDP } & $\mathrm{x}$ & 529.788 & 476.940 & 595.719 & 511.157 & 773.791 & 556.748 & 808.369 & 573.563 \\
\hline & $\mathrm{y}$ & 364.923 & 17.480 & 496.017 & 21.053 & 725.084 & 17.655 & 866.420 & 19.991 \\
\hline \multicolumn{10}{|l|}{ Rubinela } \\
\hline$R^{2} a j$ & & 0.939 & 0.936 & 0.944 & 0.937 & 0.970 & 0.939 & 0.972 & 0.944 \\
\hline AIC & & 9.097 & 3.428 & 9.322 & 3.615 & 8.397 & 2.281 & 8.558 & 2.459 \\
\hline RSD & & 12.579 & 0.657 & 13.222 & 0.696 & 14.499 & 0.909 & 15.071 & 0.938 \\
\hline PE & & 21.812 & 45.197 & 33.693 & 65.254 & 8.357 & 3.999 & 9.406 & 4.435 \\
\hline IN & & 0.218 & 0.216 & 0.215 & 0.215 & 0.129 & 0.175 & 0.126 & 0.169 \\
\hline \multirow[t]{2}{*}{ IP } & $\mathrm{x}$ & 549.183 & 651.039 & 608.003 & 713.882 & 531.316 & 420.175 & 549.160 & 433.355 \\
\hline & $\mathrm{y}$ & 150.237 & 11.759 & 217.594 & 16.284 & 202.760 & 5.596 & 235.066 & 6.342 \\
\hline \multirow[t]{2}{*}{ MAP } & $\mathrm{x}$ & 333.753 & 368.249 & 365.057 & 403.130 & 312.114 & 255.052 & 322.078 & 261.592 \\
\hline & $\mathrm{y}$ & 29.790 & 2.332 & 43.146 & 3.229 & 40.205 & 1.110 & 46.611 & 1.258 \\
\hline \multirow[t]{2}{*}{ MDP } & $\mathrm{x}$ & 764.613 & 933.829 & 850.948 & 1024.634 & 750.517 & 585.298 & 776.242 & 605.118 \\
\hline & $\mathrm{y}$ & 278.731 & 21.817 & 403.697 & 30.211 & 376.177 & 10.382 & 436.112 & 11.767 \\
\hline
\end{tabular}

Note $^{(1)} \mathrm{FLM}=$ fresh leaf matter, as g plant ${ }^{-1} ; \mathrm{DLM}=$ dry leaf matter, as $\mathrm{g} \mathrm{plant}^{-1} ; \mathrm{FSM}=$ fresh shoot matter, as $\mathrm{g}$ plant $^{-1}$; and DSM $=$ dry shoot matter, as g plant ${ }^{-1}$. 
Table 6. Coefficient of determination $\left(\mathrm{R}^{2}\right)$, Akaike information criterion (AIC), residual standard deviation (RSD), intrinsic nonlinearity (IN), nonlinearity of the parameter effect (PE), inflection point (IP), maximum acceleration point (MAP), and maximum deceleration point (MDP) of the Logistc model for characters ${ }^{(1)}$ as a function of the accumulated thermal sum (in ${ }^{\circ} \mathrm{C}$ ) of lettuce cultivars (Ceres, Gloriosa, Grandes Lagos e Rubinela) in two experiments

\begin{tabular}{|c|c|c|c|c|c|c|c|c|c|}
\hline \multirow{2}{*}{ Statistic } & & \multicolumn{4}{|c|}{ Experiment 1} & \multicolumn{4}{|c|}{ Experiment 2} \\
\hline & & FLM & DLM & FSM & DSM & FLM & DLM & FSM & DSM \\
\hline \multicolumn{10}{|l|}{ Ceres } \\
\hline$R^{2} a j$ & & 0.958 & 0.965 & 0.965 & 0.964 & 0.975 & 0.956 & 0.976 & 0.961 \\
\hline AIC & & 6.318 & 0.515 & 6.470 & 0.786 & 9.443 & 0.459 & 5.891 & 0.532 \\
\hline RSD & & 22.483 & 1.239 & 24.261 & 1.420 & 17.048 & 1.213 & 18.347 & 1.258 \\
\hline PE & & 0.534 & 1.150 & 0.705 & 1.951 & 1.487 & 1.402 & 1.789 & 1.627 \\
\hline IN & & 0.118 & 0.097 & 0.106 & 0.095 & 0.076 & 0.095 & 0.075 & 0.090 \\
\hline \multirow[t]{2}{*}{ IP } & $\mathrm{x}$ & 362.084 & 406.675 & 386.553 & 441.679 & 477.290 & 448.513 & 492.783 & 465.346 \\
\hline & $\mathrm{y}$ & 143.620 & 10.577 & 182.559 & 13.808 & 200.801 & 9.832 & 236.372 & 11.534 \\
\hline \multirow[t]{2}{*}{ MAP } & $\mathrm{x}$ & 290.671 & 305.567 & 305.747 & 329.504 & 364.731 & 336.988 & 378.153 & 350.971 \\
\hline & $\mathrm{y}$ & 60.701 & 4.470 & 77.158 & 5.836 & 84.869 & 4.155 & 99.902 & 4.875 \\
\hline \multirow{2}{*}{ MDP } & $\mathrm{x}$ & 433.497 & 507.783 & 467.360 & 553.855 & 589.850 & 560.037 & 607.413 & 579.721 \\
\hline & $\mathrm{y}$ & 226.539 & 16.684 & 287.959 & 21.780 & 316.734 & 15.508 & 372.841 & 18.193 \\
\hline \multicolumn{10}{|l|}{ Gloriosa } \\
\hline$R^{2} a j$ & & 0.959 & 0.907 & 0.963 & 0.913 & 0.959 & 0.942 & 0.961 & 0.940 \\
\hline AIC & & 6.961 & 1.436 & 6.958 & 1.483 & 6.861 & 0.676 & 6.896 & 0.845 \\
\hline RSD & & 31.047 & 1.958 & 31.014 & 2.005 & 29.759 & 1.351 & 30.288 & 1.470 \\
\hline PE & & 1.351 & 0.862 & 1.503 & 0.878 & 1.000 & 0.821 & 1.008 & 0.881 \\
\hline IN & & 0.107 & 0.173 & 0.100 & 0.165 & 0.107 & 0.112 & 0.105 & 0.115 \\
\hline \multirow{2}{*}{ IP } & $\mathrm{x}$ & 415.163 & 351.994 & 426.523 & 356.614 & 439.440 & 395.383 & 442.443 & 400.516 \\
\hline & $\mathrm{y}$ & 248.131 & 8.444 & 275.797 & 9.056 & 226.977 & 8.065 & 239.634 & 8.679 \\
\hline \multirow[t]{2}{*}{ MAP } & $\mathrm{x}$ & 315.315 & 272.229 & 323.419 & 275.362 & 346.772 & 299.807 & 349.508 & 304.259 \\
\hline & $\mathrm{y}$ & 104.873 & 3.569 & 116.566 & 3.828 & 95.932 & 3.409 & 101.281 & 3.668 \\
\hline \multirow[t]{2}{*}{ MDP } & $\mathrm{x}$ & 515.012 & 431.759 & 529.628 & 437.866 & 532.109 & 490.960 & 535.378 & 496.774 \\
\hline & $\mathrm{y}$ & 391.390 & 13.320 & 435.029 & 14.285 & 358.022 & 12.721 & 377.987 & 13.690 \\
\hline \multicolumn{10}{|c|}{ Grandes Lagos } \\
\hline$R^{2} a j$ & & 0.966 & 0.961 & 0.964 & 0.962 & 0.969 & 0.850 & 0.968 & 0.859 \\
\hline AIC & & 6.555 & 0.946 & 6.836 & 1.081 & 6.655 & 2.082 & 6.847 & 2.179 \\
\hline RSD & & 25.321 & 1.532 & 29.145 & 1.640 & 26.874 & 2.730 & 29.585 & 2.866 \\
\hline PE & & 0.911 & 0.695 & 1.310 & 0.840 & 1.625 & 1.696 & 1.865 & 1.772 \\
\hline IN & & 0.102 & 0.111 & 0.104 & 0.108 & 0.085 & 0.177 & 0.087 & 0.172 \\
\hline \multirow[t]{2}{*}{ IP } & $\mathrm{x}$ & 403.304 & 381.132 & 424.484 & 394.111 & 476.856 & 405.174 & 485.628 & 412.937 \\
\hline & $\mathrm{y}$ & 208.692 & 10.770 & 252.783 & 12.299 & 284.882 & 10.074 & 319.187 & 11.165 \\
\hline \multirow[t]{2}{*}{ MAP } & $\mathrm{x}$ & 315.390 & 301.297 & 330.136 & 309.159 & 365.169 & 299.881 & 372.708 & 306.462 \\
\hline & $\mathrm{y}$ & 88.204 & 4.552 & 106.839 & 5.198 & 120.405 & 4.258 & 134.904 & 4.719 \\
\hline \multirow[t]{2}{*}{ MDP } & $\mathrm{x}$ & 491.218 & 460.967 & 518.833 & 479.062 & 588.542 & 510.468 & 598.547 & 519.412 \\
\hline & $\mathrm{y}$ & 329.181 & 16.988 & 398.727 & 19.400 & 449.359 & 15.890 & 503.470 & 17.611 \\
\hline \multicolumn{10}{|l|}{ Rubinela } \\
\hline$R^{2} a j$ & & 0.941 & 0.935 & 0.945 & 0.936 & 0.970 & 0.941 & 0.972 & 0.946 \\
\hline AIC & & 5.134 & -0.729 & 5.236 & -0.613 & 5.427 & -0.151 & 5.506 & -0.088 \\
\hline RSD & & 12.434 & 0.664 & 13.088 & 0.703 & 14.536 & 0.893 & 15.126 & 0.922 \\
\hline PE & & 3.097 & 5.607 & 3.804 & 6.974 & 1.490 & 1.095 & 1.577 & 1.146 \\
\hline IN & & 0.138 & 0.134 & 0.133 & 0.133 & 0.085 & 0.114 & 0.083 & 0.110 \\
\hline \multirow[t]{2}{*}{ IP } & $\mathrm{x}$ & 465.901 & 495.515 & 481.162 & 510.262 & 472.903 & 421.577 & 479.591 & 428.931 \\
\hline & $\mathrm{y}$ & 97.602 & 5.921 & 115.566 & 6.819 & 153.694 & 5.643 & 169.552 & 6.203 \\
\hline \multirow[t]{2}{*}{ MAP } & $\mathrm{x}$ & 368.030 & 379.519 & 381.105 & 392.095 & 363.623 & 321.235 & 369.620 & 327.172 \\
\hline & $\mathrm{y}$ & 41.252 & 2.503 & 48.844 & 2.882 & 64.959 & 2.385 & 71.661 & 2.622 \\
\hline \multirow{2}{*}{ MDP } & $\mathrm{x}$ & 563.773 & 611.510 & 581.218 & 628.430 & 582.183 & 521.919 & 589.563 & 530.689 \\
\hline & $\mathrm{y}$ & 153.953 & 9.340 & 182.289 & 10.757 & 242.428 & 8.900 & 267.443 & 9.784 \\
\hline
\end{tabular}

Note $^{(1)} \mathrm{FLM}=$ fresh leaf matter, as $\mathrm{g}$ plant $^{-1} ; \mathrm{DLM}=$ dry leaf matter, as $\mathrm{g}$ plant $^{-1} ; \mathrm{FSM}=$ fresh shoot matter, as $\mathrm{g}$ plant $^{-1}$; and DSM $=$ dry shoot matter, as $g$ plant $^{-1}$. 
Although the models showed satisfactory goodness-of-fit, for most of the traits, the Gompertz model overestimated the parameter $a$. The largest overestimation occurred for cv. Grandes Lagos, in experiment 2, with asymptotic values of 1062.3655 for FLM and 1269.4461 for FSM (Table 3), that is, these estimates were exceedingly higher than the maximum values observed in the dataset, which were $500.88 \mathrm{~g} \mathrm{plant}^{-1}$ for FLM and $541.26 \mathrm{~g} \mathrm{plant}^{-1}$ for FSM. Overestimation of parameter $a$ also occurred with cv. Rubinela, in experiment 1, with estimated values of 31.9655 for DLM and 44.2640 for DSM, which were higher than the maximum values of 10.00 $\mathrm{g} \mathrm{plant}^{-1}$ of DLM and $10.51 \mathrm{~g} \mathrm{plant}^{-1}$ of DSM found in the data set. Overestimation of parameters in the Gompertz model was also reported in the description of strawberry production (Diel et al., 2018).

Intrinsic nonlinearity (IN) and parameter-effects nonlinearity (PE) are used to help to determine the most suitable model. The logistic model had lower IN values for most of the traits of the cultivars in the two experiments and smaller PE than the Gompertz model (Tables 5 and 6). The lower IN and, especially PE, indicate better suitability of the logistic model. It is also worth noting that the high values of PE of the Gompertz model for cv. Rubinela (experiment 1) in relation to DLM (45.197) and FSM (65.254) are associated with overestimation of parameters. High PE values were also found in the curve fitting of the Gompertz model to salad-type tomato data (Sari et al., 2019).

The findings of this study implies that, regardless of cultivation, trait, and experiment, the logistic model is the most suitable for describing the growth of lettuce cultivars, as it exhibits a close to the ideal behavior, based on the five measures of goodness of fit ( $\mathrm{R}^{2} \mathrm{aj}, \mathrm{AIC}, \mathrm{RSD}, \mathrm{IN}$, and PE). Cultivar Ceres was selected from experiment 1 to serve as an example of the shape of the logistic growth curve of each trait, with the respective critical points (Figure 1). The other growth curves can be constructed using the respective parameter estimates (Table 3 ).

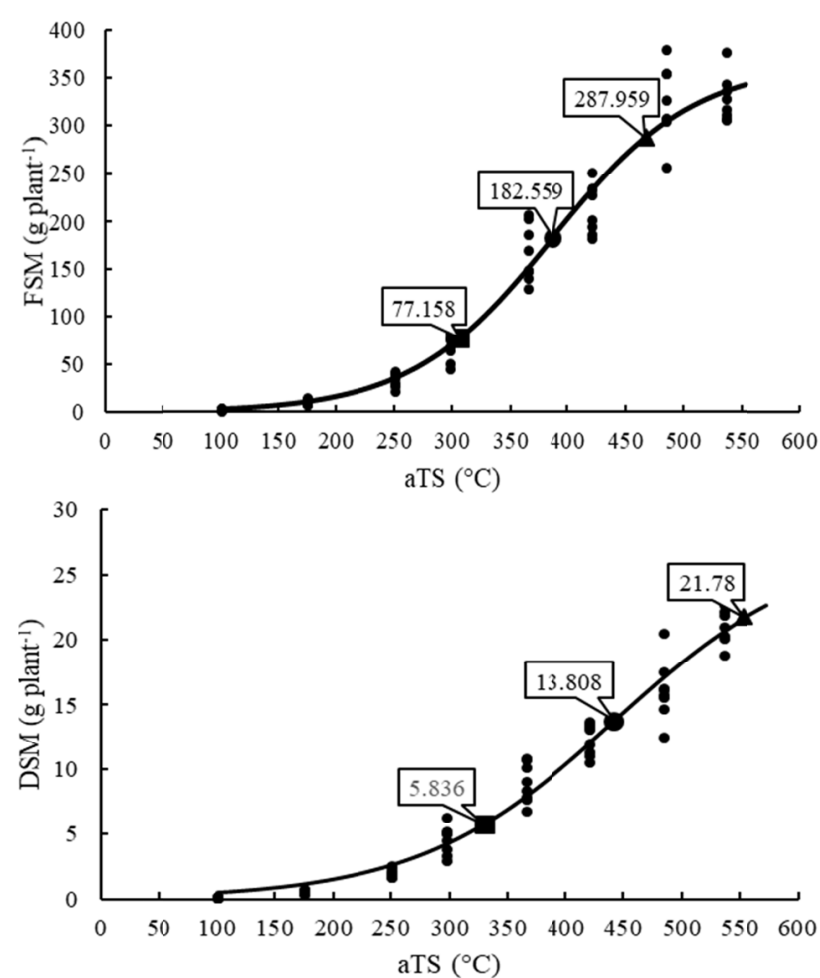

Figure 1. Logistic model plot for fresh leaf matter (FLM, as g plant $\left.{ }^{-1}\right)$, dry leaf matter (DLM as $g$ plant $\left.^{-1}\right)$, fresh shoot matter (FSM, as g plant ${ }^{-1}$ ), and shoot dry matter (DSM, as $\mathrm{g} \mathrm{plant}^{-1}$ ) as a function of the accumulated thermal sum $\left(\mathrm{aTS}\right.$, as $\left.{ }^{\circ} \mathrm{C}\right)$, for the cultivator Ceres, in experiment 2

Note. - maximum acceleration point (MAP); • inflection point (IP); $₫$ maximum deceleration point (MDP).

The maximum acceleration point (MAP) occurred at the beginning of the curve, when the plants had small volume and young leaves (Tables 5 and 6). In most cultivars, in both experiments, the inflection point (PI) is the closest to the harvest stage, for most traits and cultivars, due to the appearance of senescent outer leaves. Therefore, the critical points are important for a better understanding of the growth curve and its biological responses. Regarding 
the aTS among the cultivars, in the logistic model, cv. Ceres required the lowest accumulated thermal sum and showed lower values for the traits than cultivars Gloriosa and Grandes Lagos, which accumulated higher aTS values. Opposite behavior was observed for cv. Rubinela, with higher aTS and lower FLM compared with other cultivars.

Therefore, the results of this study indicate that the cultivar of the group purple crisp lettuce produced smaller plants, independent of the accumulated thermal sum. This study confirms that the logistic model and its critical points are important to assist in the selection of promising lettuce cultivars. The logistic model was also indicated to describe the length, diameter, and volume of the pequi fruit (Caryocar brasiliense) (Rodrigues, Mattos, Morais, $\&$ Muniz, 2018) and to describe the production curve of strawberry cultivars (Diel et al., 2018).

The parameters $(a, b$, and $c)$ can be used for the simulation and prediction of growth in the research or production of cultivars Ceres, Gloriosa, Grandes Lagos, and Rubinela, in the spring. However, it is advisable to use the thermal sum of the growing site in order to obtain responses close to the real growing conditions. In this way, predictions can be used, but the values obtained will approximate those found in this study and will follow the growth curve pattern. In addition, because studies addressing the theme are scarce, these models are a reference for further research on these cultivars growing in the spring.

\section{Conclusions}

The logistic and Gompertz growth models satisfactorily fit the fresh and dry leaf and shoot matters of cultivars Ceres, Gloriosa, Grandes Lagos, and Rubinela, under spring conditions. The Logistic model was shown the most suitable to describe the growth of lettuce cultivars.

\section{Acknowledgements}

To the Conselho Nacional de Desenvolvimento Científico e Tecnológico (CNPq-Processes 401045/2016-1 and 304652/2017-2) and the Coordenação de Aperfeiçoamento de Pessoal de Nível Superior (Capes) for the scholarships granted. Students who assisted in data collection.

\section{References}

Alvares, C. A., Stape, J. L., Sentelhas, P. C., Gonçalves, J. L. M., \& Sparovek, G. (2013). Köppen’s climate classification map for Brazil. Meteorologische Zeitschrift, 22(6), 711-728. https://doi.org/10.1127/09412948/2013/0507

Arnold, C. T. (1959). The determination and significance of the base temperature in a linear heat unit system. Proceedings of the American Society for Horticultural Science, 74, 430-455.

Bates, D. M., \& Watts, D. G. (1998). Nonlinear regression analysis and its applications. New York, John Wiley \& Sons.

Bem, C. M., Cargnelutti Filho, A., Chaves, G. G., Kleinpaul, J. A., Pezzini, R. V., \& Lavezo, A. (2018). Gompertz and Logistic models to the productive traits of sunn hemp. Journal of Agricultural Science, 10(1), 225-238. https://doi.org/10.5539/jas.v10n1p225

Breusch, T., \& Pagan, A. (1979). Teste simples para heterocedasticidade e coeficiente de variação aleatória econométrica. Sociedade Econométrica, 47, 1287-1294. https://doi.org/10.2307/1911963

Brunini, O. (1976). Temperatura-base para alface cultivar "white boston", em um sistema de unidades térmicas. Bragantia, 35(19), 213-219. https://doi.org/10.1590/S0006-87051976000100019

CEAGESP (Companhia de Entrepostos e Armazéns Gerais de São Paulo). (2017). Retrieved from http://www. ceagesp.gov.br/guia-ceagesp/alface-crespa

Diel, M. I., Sari, B. G., Krysczun, D. K., Olivoto, T., Pinheiro, M. V. M., Meira, D., ... Lúcio, A. D. (2018). Nonlinear regression for description of strawberry (Fragaria $\times$ ananassa) production. The Journal of Horticultural Science and Biotechnology, 1-15. https://doi.org/10.1080/14620316.2018.1472045

Fernandes, T. J., Pereira, A. A., Muniz, J. A., \& Savian, T. V. (2014). Selection of nonlinear models for the description of the growth curves of coffee fruit. Coffee Science, 9(2), 207-215.

Gilmore, E. C., \& Rogers, J. S. (1958). Heat units as a method of measuring maturity in corn. Agronomy Journal, 50(10), 611-615. https://doi.org/10.2134/agronj1958.00021962005000100014x

Kosma, C., Triantafyllidis, V., Papasavvas, A., Salahas, G., \& Patakas, A. (2013). Yield and nutritional quality of greenhouse lettuce as affected by shading and cultivation season. Emirates Journal of Food and Agriculture, 25(12), 974-979. https://doi.org/10.9755/ejfa.v25i12.16738 
Kuinchtner, A., \& Buriol, G. A. (2001). The climate of Rio Grande do Sul state according to kóppen and thornthwaite classification. Disciplinarum Scientia: Ciencias Exatas, 2(1), 171-182.

Lúcio, A. D., Nunes, L. F., \& Rego, F. (2015). Nonlinear models to describe production of fruit in Cucurbita pepo and Capiscum annuum. Scientia Horticulturae, 193, 286-293. https://doi.org/10.1016/j.scienta.2015. 07.021

Macedo, C. S. (2004). Ajuste de modelos de crescimento da alface (Lactuca sativa L.) cultivada em sistema hidropônico e estimativa da variação da condutividade elétrica da solução nutritiva (Unpublished MAESTRIA dissertation, Universidade Federal de Viçosa, Viçosa, Brazil).

Martin, C., Butelli, E., Petroni, K., \& Tonelli, C. (2011). How Can Research on Plants Contribute to Promoting Human Health? The Plant Cell, 23, 1685-1699. https://doi.org/10.1105/tpc.111.083279

Maynard, D. N., \& Hochmuth, G. J. (2007). Knott's handbook or vegetable growers (5th ed., p. 621). Editora John Wiley e Sons.

Mischan, M. M., \& Pinho, S. Z. (2014). Modelos não lineares: funções assintóticas de crescimento. São Paulo, Cultura Acadêmica.

Nelder, J. A. (1961). The fitting of a generalization of the logistic curve. Biometrics, 17(1), 89-110. https://doi.org/10.2307/2527498

Pereira, A. P., Fernandes, T. J., Scalco, M. S., \& Morais, A. R. (2016). Modeling nonlinear growth in height Coffee with and without irrigation in diferente densities. Irriga, 1(1), 140-149. https://doi.org/ 10.15809/irriga.2016v1n1p140-149

Puiatti, G. A., Cecon, P. R., Nascimento, M., Puiatti, M., Finger, F. L., Silva, A. R., \& Nascimento, A. C. C. (2013). Análise de agrupamento em seleção de modelos de regressão não lineares para descrever o acúmulo de matéria seca em plantas de alho. Revista Brasileira de Biometria, 31(3), 337-351.

$\mathrm{R}$ development Core Team. (2018). R: A language and environment for statistical computing. R Foundation for Statistical Computing, Vienna, Austria. Retrieved from http://www.R-project.org/

Rodrigues, T. D., Mattos, R. W. P., Morais, A. R. M., \& Muniz, J. A. (2018). Description of the growth of pequi fruits by nonlinear models. Revista Brasileira de Fruticultura, 40(4), 1-11.

Santos, C. E., Kist, B. B., Carvalho, C., Reetz, E. R., Muller, I., Belig, R. R., \& Poll, H. (2015). Anuário Brasileiro de hortaliças (p. 68). Editora Gazeta.

Sari, B. G., Lúcio, A. D., Santana, C. S., \& Savian, T. V. (2019). Describing tomato plant production using growth models. Scientia Horticulturae, 246, 146-154. https://doi.org/10.1016/j.scienta.2018.10.044

Shapiro, S. S., \& Wilk, M. B. (1965). An analysis of variance test for normality. Biometrika, 52(3/4), 591-611. https://doi.org/10.2307/2333709

Tadić, V., Tadić, J., Milošević, S., Cingel A., Prodanović, O., Ćosić T., \& Vujčić, Z. (2017). Phenol induced physiological stress in hydroponically grown lettuce (Lactuca sativa L.). Scientia Horticulturae, 232, 71-83. https://doi.org/10.1016/j.scienta.2017.12.024

Terra, M. F., Muniz, J. A., \& Savian, T. V. (2010). Fitting Logistic and Gompertz models to the growth data of dwarf date palm (Phoenix roebelenni) fruits. Magistra, 22(1), 1-7.

Windsor, C. P. (1932). The Gompertz Curve as a Growth Curve. Proceedings of the National Academy of Sciences of the United States of America, 18(1), 1-8. https://doi.org/10.1073/pnas.18.1.1

\section{Copyrights}

Copyright for this article is retained by the author(s), with first publication rights granted to the journal.

This is an open-access article distributed under the terms and conditions of the Creative Commons Attribution license (http://creativecommons.org/licenses/by/4.0/). 